\title{
Evaluation of Heat Evolution of Pastes Containing High Volume of Ground River Sand and Ground Granulated Blast Furnace Slag
}

\author{
Punnaman NORRARAT, Weerachart TANGCHIRAPAT, Chai JATURAPITAKKUL *
}

Department of Civil Engineering, Faculty of Engineering, King Mongkut's University of Technology Thonburi, Bangkok 10140, Thailand

cross $^{\text {ref }}$ http://dx.doi.org/10.5755/j01.ms.23.1.13579

Received 05 November 2015; accepted 31 January 2016

\begin{abstract}
This paper investigated the heat evolution of pastes containing inert and active materials with different particle sizes. Ground river sand was used as an inert material while ground granulated blast furnace (GGBF) slag was used as an active material. Ground river sand (GRS) and GGBF slag were ground to have the same particle size and were used separately as a replacement of Portland cement type I at rates of $50-70 \%$ by weight of the binder. Heat evolution of pastes containing GRS and GGBF slag was measured using an isothermal conduction calorimeter up to $72 \mathrm{~h}$. The results showed that GRS with different particle sizes had a slight effect on the heat evolution of pastes. GGBF slag with median particle size $d_{50}$ of $4.4 \mu \mathrm{m}$ and $d_{50}$ of $17.8 \mu \mathrm{m}$ had a small effect on the heat evolution of pastes during the first $24 \mathrm{~h}$, and the pastes also had very low heat evolution for up to $72 \mathrm{~h}$. At the same replacement rate of Portland cement, however, the heat evolution due to the slag reaction was slightly increased when the particle size of the GGBF slag was decreased. Finally, the higher is the cement replacement by GGBF slag, the higher is the slag reaction.

Keywords: heat evolution, inert material, active material, river sand, particle size, slag reaction.
\end{abstract}

\section{INTRODUCTION}

Blast furnace slag (BFS) is a by-product of the production of pig iron and consists of silicates and aluminosilicates of calcium. BFS exhibits hydraulic cementing properties when it is finely ground, and it is called ground granulated blast furnace (GGBF) slag when it is in that state [1]. GGBF slag has been used as a supplementary cementitious material (SCM) in blended cement for more than a century [2]. Annual worldwide production of GGBF slag has been estimated at 250 million tons per year [3]. The benefits of GGBF slag as a partial replacement of cement in concrete production include the enhancement of long-term strength and durability [4-6]. In addition, the cost of the concrete is reduced, and environmental problems due to the reduction of Portland cement production are mitigated $[7,8]$.

Hydration of ordinary Portland cement (OPC) and the GGBF slag reaction are chemical reactions between Portland cement, GGBF slag, and water. It is very complex and is an exothermic process. The major products of hydration are calcium silicate hydrate $(\mathrm{C}-\mathrm{S}-\mathrm{H})$, calcium aluminate hydrate, and calcium hydroxide. The glass contents or amorphous phase from GGBF slag can be dissolved by hydroxyl ions liberated during the cement hydration; thereafter, GGBF slag can also react with sodium and potassium alkalis and calcium hydroxide to create additional $\mathrm{C}-\mathrm{S}-\mathrm{H}$. In addition, the $\mathrm{CaO}$ in GGBF slag can create $\mathrm{C}-\mathrm{S}-\mathrm{H}$ from a hydration reaction similar to OPC but at a very slow rate [9]. The heat evolution of Portland cement pastes containing pozzolanic material or GGBF slag was measured using an isothermal conduction calorimeter at constant temperature in order to study the early hydration $[10,11]$.

\footnotetext{
${ }^{*}$ Corresponding author. Tel: +66-2-470-9314; fax: +66-2-427-9063.

E-mail address: chaijatura58@gmail.com (C. Jaturapitakkul)
}

Gruyaert et al. studied the hydration heat of pastes containing GGBF slag and found that the hydration heat contributed from the dilution effect, homogeneous nucleation, and gypsum content, at various cement replacement levels ranging from $30 \%$ to $85 \%$ [12]. Douglas et al. and Bougara et al. studied the reactivity of GGBF slag with different sizes and sources using an isothermal conduction calorimeter. They found that the partial replacement of Portland cement with GGBF slag reduces the heat evolution during the first $72 \mathrm{~h}[13,14]$. Han et al. and $\mathrm{Ma}$ et al. found that temperature affects the heat evolution specifically that the heat evolution of GGBF slag increases with the increase of the temperature $[15,16]$. However, their study did not specify how much of the heat evolution of paste containing GGBF slag is contributed from cement hydration and from slag reaction.

The heat evolution during the hydration process is an important factor to consider for mass concretes, hot and cold weather concreting, and determining the reactivity. If the temperature difference within the mass concrete is too high, the concrete tends to crack due to differential expansion caused by different temperatures in the concrete that leads to a reduction in the durability of the concrete [17]. Gajda and Geem recommended that the allowable temperature difference between the core and the surface of a mass concrete structure should not exceed $19^{\circ} \mathrm{C}$ [18]. To reduce the temperature effect, the replacement of Portland cement with an optimal dosage of pozzolan, such as fly ash and GGBF slag, can reduce the proportion of cement used in the concrete mix proportion and, thus, reduce the heat evolution, resulting in decreased thermal cracking during the early age of concrete structures [19]. 
The aim of this paper is to investigate the heat evolution of pastes containing non-reactive crystalline material (ground river sand) and GGBF slag.

The heat evolution contributed from cement hydration and slag reaction is analyzed and presented. Heat evolution produced by chemical reaction or physical changes as a function of time is measured using an isothermal conduction calorimeter at a constant temperature. The results will lead to a greater understanding of the heat evolution, cement hydration, and slag reaction of GGBF slag with different particle sizes. The findings would benefit users who apply GGBF slag in high volume for use in mass concrete.

\section{MATERIAL AND METHODS}

\subsection{Materials}

The main materials used in this study consisted of Portland cement type I (OPC), ground local river sand (GRS), and ground granulated blast furnace (GGBF) slag. GGBF slag is a by-product of the production of pig iron from Rayong Province, Thailand. OPC was used as a cementitious material while GRS was used as a non-reactive crystalline material.

To investigate the heat evolution and slag reaction, a non-reactive crystalline material (ground local river sand or GRS) was prepared and used in this study. To obtain GRS, local river sand was washed to get rid of impurities and carefully ground until the median particle sizes were the same as those of GGBF slag.

For large particle size: GRS and GGBF slag were separately and carefully ground to have the same median particle size $\left(d_{50}\right)$ of $18 \pm 1 \mu \mathrm{m}$. This size is specified as $L$ (large-sized). It is noted that the $L$ size of GRS and GGBF slag are almost the same size as that of OPC, which has $d_{50}$ of $18.1 \mu \mathrm{m}$. The intention of this process is to avoid the packing effect due to different particle sizes because GRS and GGBF slag have the same particle size as that of OPC.

For small particle size: GRS and GGBF slag were separately ground to have a median particle size of $5 \pm 1 \mu \mathrm{m}$. This size is specified as $S$ (small-sized) and is smaller than that of OPC. The intention of this process is to use SGRS and SGGBF slag that have a smaller particle size than OPC to investigate the heat evolution of pastes due to the packing effect of the small particle size.

OPC, GRS, and GGBF slag were measured for their $d_{50}$ and particle size distributions by Sympatee's laser diffraction particle size analyzer (HELOS/H2399 \& RODOS), and the procedure was in accordance with ISO 13320 [20]. Fig. 1 shows the comparison of the particle size distributions of OPC, GRS, and GGBF slag. It should be noted that the particle size distributions of OPC, LGRS, and LGGBF slag are nearly the same, and the median particle size, $d_{50}$, of the materials are in the range of $18 \pm 1 \mu \mathrm{m}$, whereas SGRS and SGGBF slag have slightly different in particle size distributions and the $d_{50}$ of both materials are in the range of $5 \pm 1 \mu \mathrm{m}$.

\subsection{Physical properties of the materials}

Physical properties of OPC, GRS, and GGBF slag with different particle sizes are given in Table 1 . Specific gravity and the particle retained on a sieve No. 325 of the materials were determined in accordance with ASTM C 188 [21] and C 430 [22], respectively. The median particle size $\left(d_{50}\right)$ of OPC is $18.1 \mu \mathrm{m}$, while those for LGRS and SGRS are 17.7 and $4.8 \mu \mathrm{m}$, respectively. LGGBF and SGGBF slag have median particle sizes, $d_{50}$, of 17.8 and $4.4 \mu \mathrm{m}$, respectively.

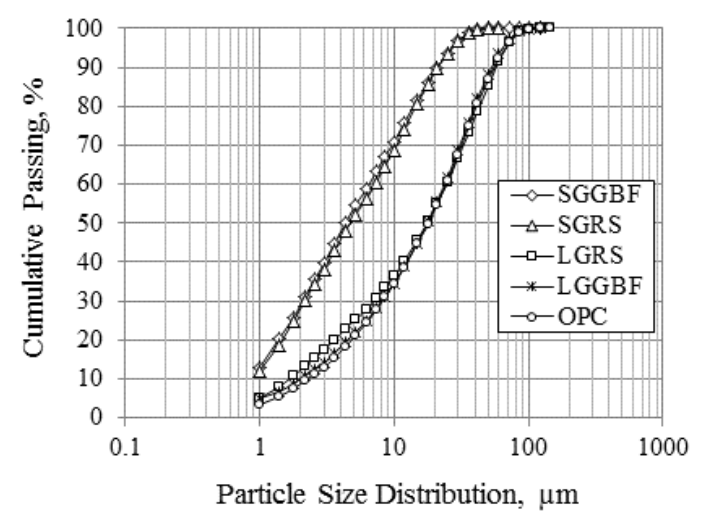

Fig. 1. Particle size distributions of the materials

Table 1. Physical properties of OPC, GRS, and GGBF slag

\begin{tabular}{|c|c|c|c|}
\hline Material & $\begin{array}{c}\text { Specific } \\
\text { gravity }\end{array}$ & $\begin{array}{c}\text { Retained on } \\
\text { a No.325 sieve, } \\
\%\end{array}$ & $\begin{array}{c}\text { Median particle } \\
\text { size, } \mu \mathrm{m}\end{array}$ \\
\hline OPC & 3.15 & 16.6 & 18.1 \\
\hline LGRS & 2.61 & 17.9 & 17.7 \\
\hline SGRS & 2.63 & 1.1 & 4.8 \\
\hline LGGBF & 2.92 & 12.2 & 17.8 \\
\hline SGGBF & 2.92 & 2.4 & 4.4 \\
\hline
\end{tabular}

The mineralogical compositions of GRS and GGBF slag were determined by quantitative X-ray diffraction analysis, as shown in Table 2. LGRS and SGRS have $100 \%$ crystalline phases such as quartz, microcline, albite, and muscovite whereas LGGBF and SGGBF slag have 99.2 and $99.6 \%$ amorphous or glass content. Because LGRS and SGRS have $100 \%$ crystalline phases, they cannot react with OPC or GGBF slag to form any hydration products. Fig. 2 shows the X-ray diffraction patterns of SGGBF slag and SGRS, respectively. The figures also show that SGRS is mostly in a crystalline phase, whereas SGGBF slag is in an amorphous phase. The particle shapes of OPC, LGRS, and LGGBF slag are shown in Fig. 3, and all of them are solid with angular particle shapes.

\subsection{Chemical compositions of materials}

Chemical compositions of OPC, SGRS, and SGGBF slag, which were determined using X-ray fluorescence, are shown in Table 3. The main chemical components of OPC are $\quad 65.0 \% \mathrm{CaO}, \quad 19.5 \% \mathrm{SiO}_{2}, \quad 5.3 \% \mathrm{Al}_{2} \mathrm{O}_{3}$, and $3.2 \% \mathrm{Fe}_{2} \mathrm{O}_{3}$, whereas the chemical components of SGRS are $92.0 \% \mathrm{SiO}_{2}$ and $5.0 \% \mathrm{Al}_{2} \mathrm{O}_{3}$. The $\mathrm{SiO}_{2}$ of SGRS is in the form of quartz, thus, it is not a pozzolanic material. Similar results were reported for ground river sand, which contains approximately $91.8-92.9 \% \mathrm{SiO}_{2} \quad$ (quartz) [23-25]. The chemical components of SGGBF slag are $35.3 \% \mathrm{CaO}, 36.0 \% \mathrm{SiO}_{2}, 14.6 \% \mathrm{Al}_{2} \mathrm{O}_{3}$, and $7.1 \% \mathrm{MgO}$. Other minor components include alkali oxides and iron oxides. 
Table 2. Mineralogical compositions of GRS and GGBF slag

\begin{tabular}{|c|c|c|c|c|c|c|c|}
\hline \multirow{2}{*}{ Name } & \multicolumn{4}{|c|}{ Crystalline, $\%$} & \multirow{2}{*}{ Amorphous, \% } & \multirow{2}{*}{ Total crystalline, $\%$} & \multirow{2}{*}{ Total amorphous, $\%$} \\
\hline & Quartz & Microcline & Albite & Muscovite & & & \\
\hline LGRS & 79.4 & 13.6 & 3.9 & 3.1 & - & 100 & 0 \\
\hline SGRS & 79.4 & 13.8 & 3.8 & 3.0 & - & 100 & 0 \\
\hline LGGBF & 0.8 & - & - & - & 99.2 & 0 & 100 \\
\hline SGGBF & 0.4 & - & - & - & 99.6 & 0 & 100 \\
\hline
\end{tabular}

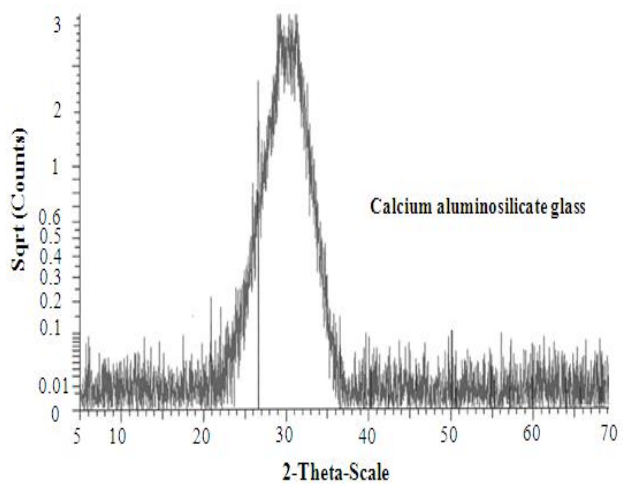

a

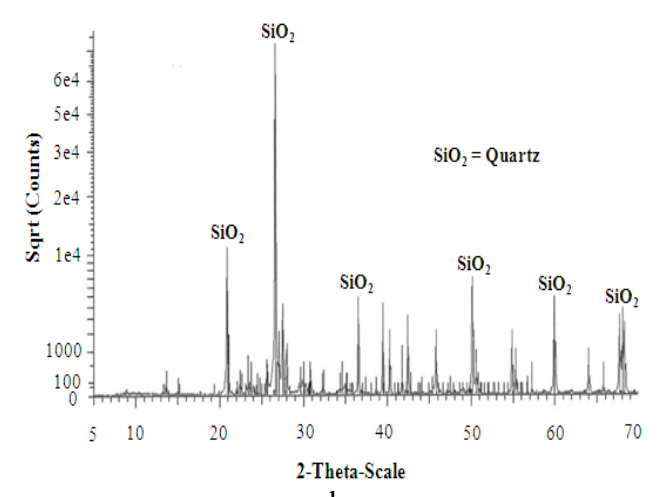

b

Fig. 2. X-ray diffraction patterns of materials: $a-S G G B F$ slag; $b-S G R S$

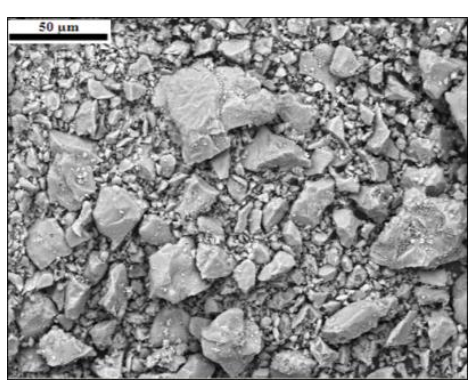

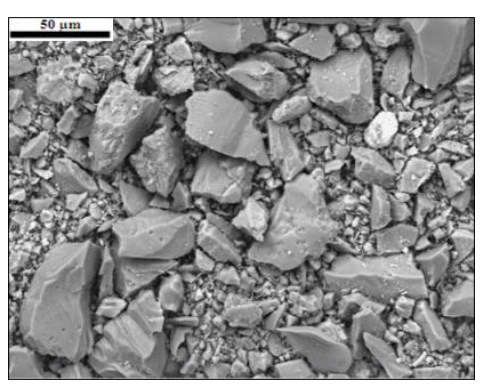

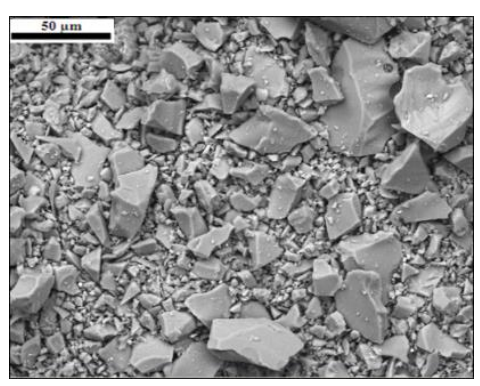

Fig. 3. Particle shapes of materials by SEM: $a-O P C ; b-L G R S ; c-L G G B F$

Table 3. Chemical compositions of OPC, SGRS, and SGGBF

\begin{tabular}{|c|c|c|c|c|c|c|c|c|c|}
\hline \multirow{2}{*}{ Name } & \multicolumn{9}{|c|}{ Chemical composition, $\%$} \\
\hline & $\overline{\mathrm{SiO}_{2}}$ & $\mathrm{Al}_{2} \mathrm{O}_{3}$ & $\mathrm{Fe}_{2} \mathrm{O}_{3}$ & $\mathrm{CaO}$ & $\mathrm{MgO}$ & $\mathrm{SO}_{3}$ & $\mathrm{Na}_{2} \mathrm{O}_{3}$ & $\mathrm{~K}_{2} \mathrm{O}$ & $\overline{\text { LOI }}$ \\
\hline$\overline{\mathrm{OPC}}$ & 19.5 & 5.3 & 3.2 & 65.0 & 0.8 & 2.7 & 0.1 & 0.4 & 2.4 \\
\hline SGRS & 92.0 & 5.0 & 0.6 & 0.2 & 0.1 & 0.0 & 0.4 & 0.8 & 0.1 \\
\hline SGGBF & 36.0 & 14.6 & 1.9 & 35.3 & 7.1 & 2.0 & 0.9 & 0.2 & 0.1 \\
\hline
\end{tabular}

\subsection{Heat evolution of paste}

To evaluate the heat evolution, three types of pastes, control paste made with OPC (control paste), non-reactive crystalline material pastes (GRS pastes), and GGBF slag pastes, were prepared and investigated in this study. Two particle sizes of GRS (LGRS and SGRS) and GGBF slag (LGGBF and SGGBF slag) were used separately to replace OPC at rates of $0,50,60$, and $70 \%$ by weight of the binder $(\mathrm{OPC}+\mathrm{GRS}$ or OPC + GGBF slag) to cast pastes. The water to binder (W/B) ratio of all pastes was kept constant at 0.50 . The mix proportions of OPC paste and pastes containing GRS and GGBF slag are shown in Table 4.

To measure the heat evolution of the pastes, a thermal activity monitor (the TAM Air calorimeter from TA Instruments, No. 387, USA) was used, and the procedure was in accordance with ASTM C 1702 [26]. The TAM Air calorimeter is shown in Fig. 4. The TAM Air contains 8 parallel twin calorimeters (sample and reference) as the type of measurement channels. The binders are prepared and then placed in two glass ampoules at a controlled temperature of $25^{\circ} \mathrm{C}$ and inserted in the TAM Air calorimeter with the same temperature.

Table 4. Mix proportions of pastes by weight

\begin{tabular}{|c|c|c|c|c|}
\hline Mixture & OPC & GRS & GGBF & W/B \\
\hline Control & 1 & - & - & 0.5 \\
\hline LGRS50 & 0.5 & 0.5 & - & 0.5 \\
\hline LGRS60 & 0.4 & 0.6 & - & 0.5 \\
\hline LGRS70 & 0.3 & 0.7 & - & 0.5 \\
\hline SGRS50 & 0.5 & 0.5 & - & 0.5 \\
\hline SGRS60 & 0.4 & 0.6 & - & 0.5 \\
\hline SGRS70 & 0.3 & 0.7 & - & 0.5 \\
\hline LGGBF50 & 0.5 & - & 0.5 & 0.5 \\
\hline LGGBF60 & 0.4 & - & 0.6 & 0.5 \\
\hline LGGBF70 & 0.3 & - & 0.7 & 0.5 \\
\hline SGGBF50 & 0.5 & - & 0.5 & 0.5 \\
\hline SGGBF60 & 0.4 & - & 0.6 & 0.5 \\
\hline SGGBF70 & 0.3 & - & 0.7 & 0.5 \\
\hline
\end{tabular}

The binders were OPC (or OPC+GRS, or OPC+GGBF slag), and the reference was quartz (Ottawa sand). For the mixing procedure, the combinations of OPC, OPC+GRS or 
OPC+GGBF slag and deionized water were mixed together by using plastic paddle until the uniformity of all pastes was obtained.

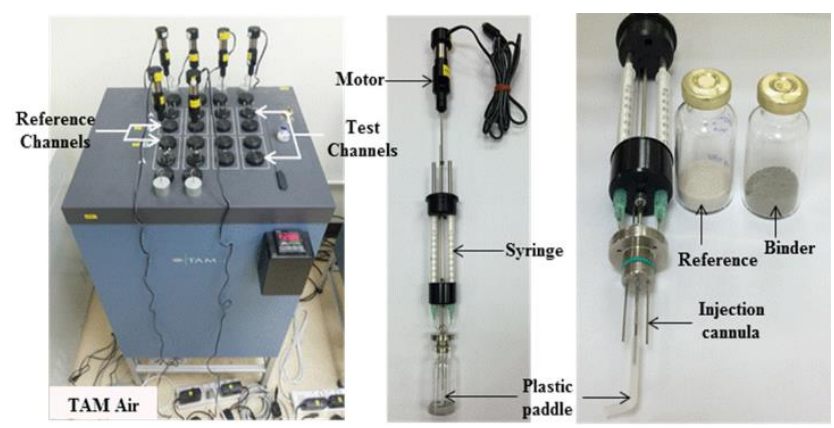

Fig. 4. Thermal activity monitor (TAM)

The signal heat flow was controlled using a computer program, and output data on the cumulative heat evolution versus time were recorded. The heat evolution was measured until the end of the testing period, which was $72 \mathrm{~h}$ after mixing.

\section{RESULTS AND DISCUSSION}

\subsection{Effect of GRS particles on the cumulative heat evolution}

Fig. 5 shows the relationship between the cumulative heat evolution and time of the OPC paste and pastes containing GRS at the cement replacement rates of 50,60, and $70 \%$ by weight of the binder, respectively.

The results indicated that the pastes, when mixed with a small particle size of SGRS $\left(d_{50}=4.8 \mu \mathrm{m}\right)$ and large particle size of LGRS $\left(d_{50}=17.7 \mu \mathrm{m}\right)$, provided a much lower cumulative heat evolution than that of the OPC paste. A similar trend was also reported by Douglas et al. who replaced Portland cement with 35 and $50 \%$ sand in the mixtures and found that the cumulative heat evolution of those pastes was the lowest compared to the OPC paste and GGBF slag paste [13].

Fig. 6 shows the cumulative heat evolution and the replacement of cement by GRS with different particle sizes at 24 and $72 \mathrm{~h}$. It revealed that the cumulative heat evolution of SGRS and LGRS pastes with the same replacement and same age were very similar. The cumulative heat evolution of LGRS paste was a little lower than that of SGRS paste at the same replacement percentage and same age. For example, the LGRS70 and SGRS70 pastes had cumulative heat evolution of 79.1 and $83.9 \mathrm{~J} / \mathrm{g}$ at $24 \mathrm{~h}$, respectively, and it increased to 120.9 and $128.0 \mathrm{~J} / \mathrm{g}$ at $72 \mathrm{~h}$, respectively, while the OPC paste had a cumulative of heat evolution of $213.7 \mathrm{~J} / \mathrm{g}$ at $24 \mathrm{~h}$, and it increased to $311.8 \mathrm{~J} / \mathrm{g}$ at $72 \mathrm{~h}$. SGRS70 paste produced a higher cumulative heat evolution than that of LGRS50 paste because the small particle size of SGRS produced a packing effect, creating a more homogeneous paste, and accelerated the hydration reaction of OPC [27].

However, it was noticed that the different particle sizes of GRS ( $d_{50}$ of $4.8 \mu \mathrm{m}$ and $17.7 \mu \mathrm{m}$ ) had a small effect on the cumulative heat evolution because GRS is a nonreactive material $\left(\mathrm{SiO}_{2}\right.$ of GRS is in the form of quartz); thus, it is not a pozzolanic material and cannot react with Portland cement to create heat due to the chemical reaction [28].

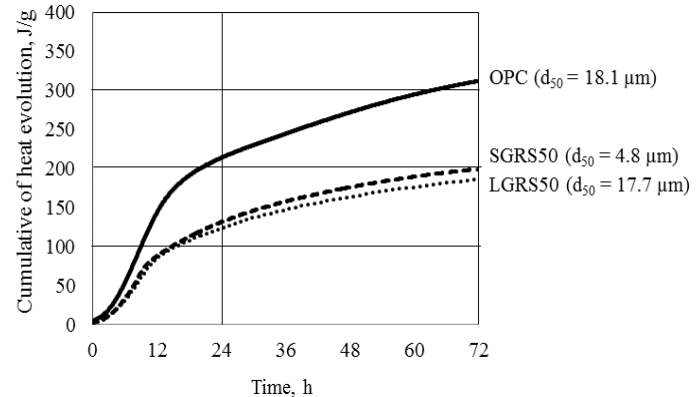

a

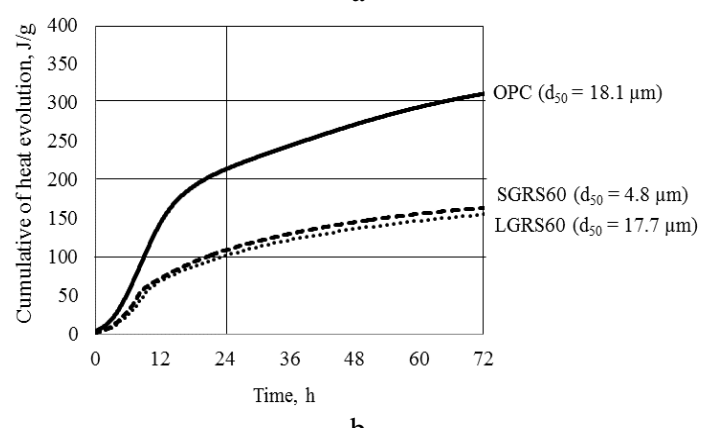

b

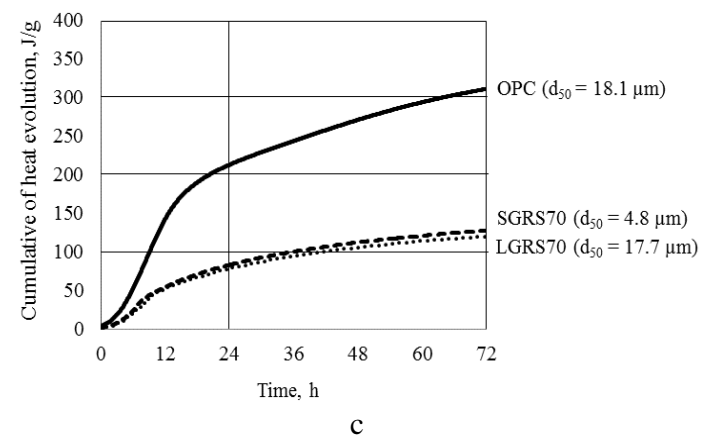

Fig. 5. Cumulative heat evolution of GRS pastes with different particle sizes: a $-50 \%$ replacement of Portland cement; $\mathrm{b}-60 \%$ replacement of Portland cement; c-70\% replacement of Portland cement

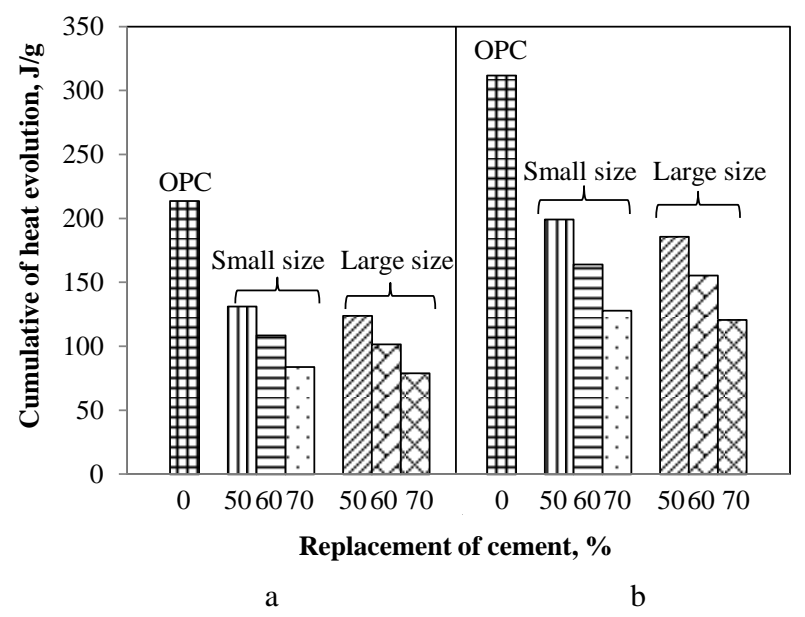

Fig. 6. Cumulative heat evolution of GRS pastes: a-24h; $\mathrm{b}-72 \mathrm{~h}$

Because OPC and LGRS have almost the same particle size distributions (both materials have $d_{50}$ of $18 \pm 1 \mu \mathrm{m}$ ), the cumulative heat evolution of LGRS50, LGRS60, and LGRS70 pastes (OPC contents of 50, 40, and $30 \%$ by weight of the binder) was assumed to be only from cement hydration. The cumulative heat evolution of LGRS pastes due to cement hydration is shown in Table 5. At the same 
ages $(12,24,36,48,60$, or $72 \mathrm{~h})$, the cumulative heat evolution due to cement hydration of GRS pastes decreased with the increase of GRS replacement.

Table 5. Cumulative heat evolution of pastes

\begin{tabular}{|c|c|c|c|c|c|c|}
\hline \multirow{2}{*}{ Name } & \multicolumn{6}{|c|}{ Cumulative of heat evolution, J/g } \\
\cline { 2 - 7 } & $12 \mathrm{~h}$ & $24 \mathrm{~h}$ & $36 \mathrm{~h}$ & $48 \mathrm{~h}$ & $60 \mathrm{~h}$ & $72 \mathrm{~h}$ \\
\hline OPC & 143.9 & 213.7 & 244.5 & 271.8 & 294.6 & 311.8 \\
\hline LGRS50 & 85.1 & 123.8 & 147.3 & 163.7 & 176.3 & 185.9 \\
\hline LGRS60 & 69.2 & 101.6 & 122.4 & 136.6 & 147.4 & 155.6 \\
\hline LGRS70 & 52.9 & 79.1 & 95.3 & 106.5 & 114.7 & 120.9 \\
\hline SGRS50 & 87.8 & 131.3 & 157.6 & 175.8 & 189.4 & 199.2 \\
\hline SGRS60 & 72.6 & 108.8 & 130.4 & 145.5 & 156.4 & 164.1 \\
\hline SGRS70 & 55.3 & 83.9 & 101.0 & 113.0 & 121.5 & 128.0 \\
\hline LGGBF50 & 79.2 & 115.8 & 140.5 & 158.7 & 173.6 & 186.6 \\
\hline LGGBF60 & 62.1 & 95.4 & 118.0 & 135.8 & 150.4 & 162.8 \\
\hline LGGBF70 & 46.8 & 72.8 & 92.7 & 109.4 & 124.0 & 136.9 \\
\hline SGGBF50 & 76.2 & 120.9 & 152.3 & 178.0 & 199.8 & 218.5 \\
\hline SGGBF60 & 62.0 & 99.0 & 128.5 & 153.8 & 175.8 & 195.2 \\
\hline SGGBF70 & 45.5 & 75.1 & 101.5 & 127.3 & 150.7 & 170.7 \\
\hline
\end{tabular}

For example, the cumulative heat evolution of OPC paste was $213.7 \mathrm{~J} / \mathrm{g}$ at $24 \mathrm{~h}$, and it increased to $311.8 \mathrm{~J} / \mathrm{g}$ at $72 \mathrm{~h}$, while those of the LGRS50, LGRS60, and LGRS70 pastes were 123.8, 101.6, and 79.1 J/g (approximately 57.9, 47.5 , and $37.0 \%$ of OPC paste) at $24 \mathrm{~h}$ and then slightly increased to $185.9,155.6$, and $120.9 \mathrm{~J} / \mathrm{g}$ (approximately $59.6,49.9$, and $38.8 \%$ of OPC paste) at $72 \mathrm{~h}$.

\subsection{Effect of GGBF slag particles on the cumulative heat evolution}

The cumulative heat evolution of pastes containing GGBF slag at cement replacement rates of 50, 60, and $70 \%$ by weight of the binder compared to Portland cement paste (OPC paste) is shown in Fig. 7. It was found that the OPC paste $\left(d_{50}=18.1 \mu \mathrm{m}\right)$ had the highest cumulative heat evolution of $213.7 \mathrm{~J} / \mathrm{g}$ at $24 \mathrm{~h}$, and it increased to $311.8 \mathrm{~J} / \mathrm{g}$ at $72 \mathrm{~h}$. This result was close to the result obtained by Bougara et al. who found that the cumulative heat evolution of OPC was $290 \mathrm{~J} / \mathrm{g}$ at $72 \mathrm{~h}$ [14].

Fig. 7 show that the cumulative heat evolution of OPC, SGGBF, and LGGBF pastes increased very quickly up to $12 \mathrm{~h}$ and increased constantly afterwards. In addition, the cumulative heat evolution of pastes containing GGBF slag decreased with the increase of GGBF slag replacement. This is due to the reduction of Portland cement which has higher heat evolution than GGBF slag. The cumulative heat evolution of pastes mixed with $\operatorname{SGGBF}\left(d_{50}=4.4 \mu \mathrm{m}\right)$ and LGGBF $\left(d_{50}=17.8 \mu \mathrm{m}\right)$ was much lower than that of the OPC $\left(d_{50}=18.1 \mu \mathrm{m}\right)$ paste at the same age. For example, the SGGBF70 and LGGBF70 pastes had a cumulative heat evolution of $170.7 \mathrm{~J} / \mathrm{g}$ and $136.9 \mathrm{~J} / \mathrm{g}$, i.e., only 54.7 and $43.9 \%$ of OPC paste, at $72 \mathrm{~h}$, respectively. This confirmed that the use of GGBF slag to replace OPC can reduce the heat evolution of concrete which is an important factor to be considered in mass concrete structures. This result is also consistent with the previous research [12-14] that concluded that GGBF slag can be used to reduce the heat evolution of concrete.

The cumulative heat evolution and the replacement of cement by GGBF slag with different particle sizes at 24 and $72 \mathrm{~h}$ is illustrated in Fig. 8. The figures show that the cumulative heat evolution of the small particle size and large particle sizes of GGBF pastes are slightly different at $24 \mathrm{~h}$.

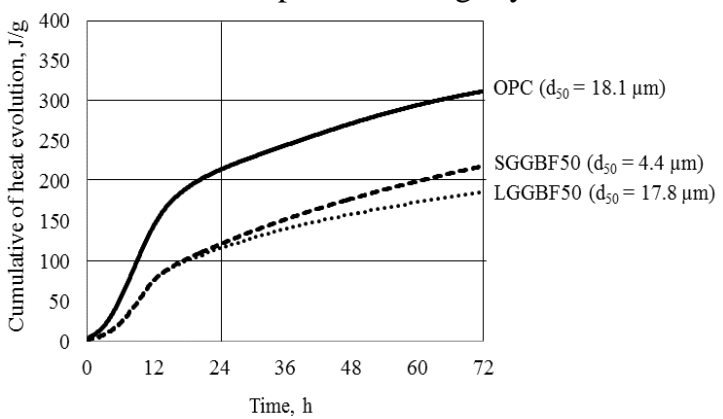

a

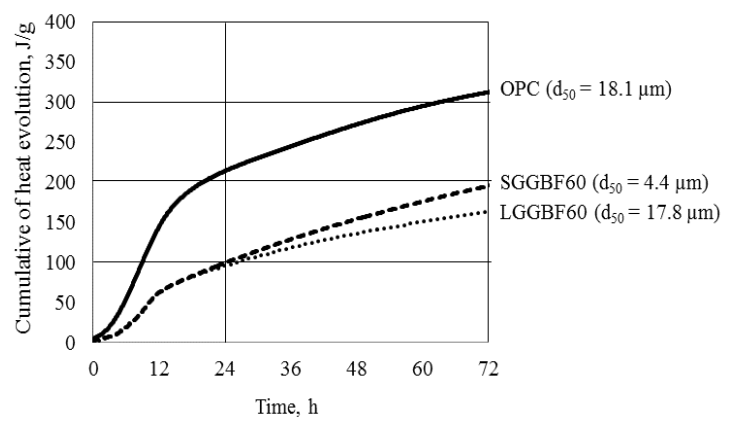

b

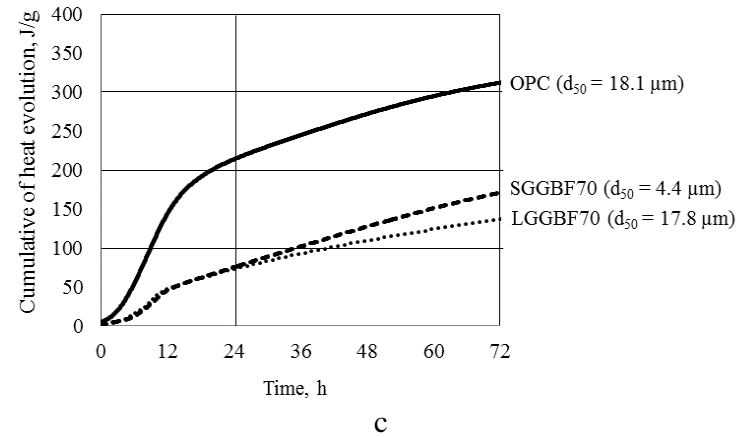

Fig. 7. Cumulative heat evolution of GGBF pastes with different particle sizes: $a-50 \%$ replacement of OPC; $b-60 \%$ replacement of OPC; $\mathrm{c}-70 \%$ replacement of OPC

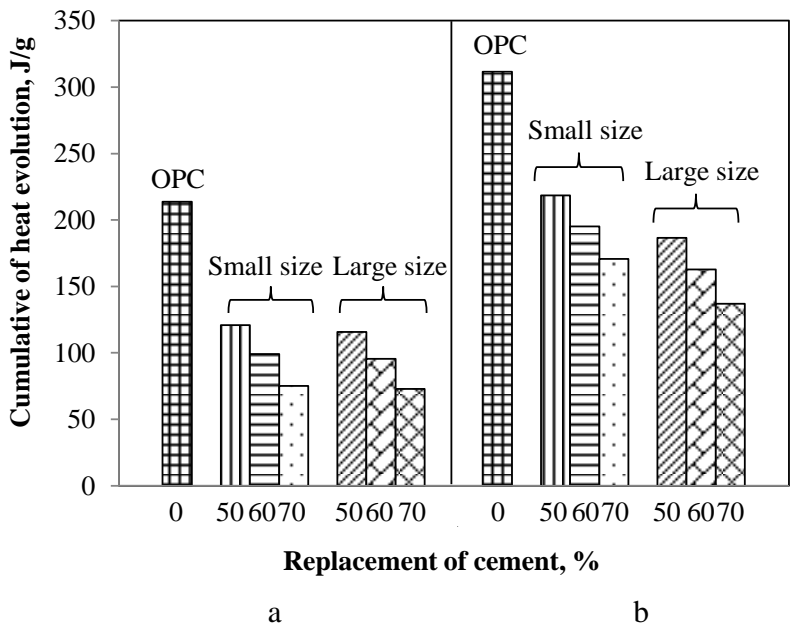

Fig. 8. Cumulative heat evolution of GGBF slag pastes: $a-24 h$; $\mathrm{b}-72 \mathrm{~h}$

However, the pastes with the smaller size of GGBF slag tend to produce a higher cumulative heat evolution than does the larger size at $72 \mathrm{~h}$. Similar results were also reported by Zhang, et al. who found that the heat evolution 
of paste containing GGBF slag increased with the increased of GGBF slag fineness [10]. For example, LGGBF50 paste had a cumulative heat evolution of $115.8 \mathrm{~J} / \mathrm{g}$ at $24 \mathrm{~h}$, and it increased to $186.6 \mathrm{~J} / \mathrm{g}$ at $72 \mathrm{~h}$, while SGGBF50 paste had a cumulative heat evolution of $120.9 \mathrm{~J} / \mathrm{g}$ at $24 \mathrm{~h}$, and it increased to $218.5 \mathrm{~J} / \mathrm{g}$ at $72 \mathrm{~h}$. This is due to the smaller size of SGGBF slag having a higher surface area than LGGBF slag, thus increasing the slag activity and acting as nucleation sites $[29,30]$ to promote the cement hydration and slag reaction.

\subsection{Cumulative heat evolution due to the slag reaction}

One objective of this study is to determine the value of the cumulative heat evolution due to the slag reaction. To obtain this, the cumulative heat evolution of paste due to the packing effect of the small particles has to be considered and taken out from the total cumulative heat evolution. Thus, the difference in the cumulative heat evolution between GGBF slag paste and GRS paste at the same particle size, same replacement, same $\mathrm{W} / \mathrm{B}$ ratio, and same age is the cumulative heat evolution due to the slag reaction of GGBF slag. For example, the cumulative heat evolution due to the slag reaction of SGGBF70 paste at $72 \mathrm{~h}$ can be calculated by using the cumulative heat evolution of paste SGGBF70 (170.7 J/g) in Table 5 minus the cumulative heat evolution of SGRS50 paste $(128.0 \mathrm{~J} / \mathrm{g})$ in Table 5 , which is equal to $42.7 \mathrm{~J} / \mathrm{g}$ in Table 6.

Table 6. Values of cumulative heat evolution of pastes due to the slag reaction

\begin{tabular}{|c|c|c|c|c|c|c|c|}
\hline \multirow{2}{*}{ Compared paste } & \multirow{2}{*}{\begin{tabular}{|c|} 
Size of \\
material \\
particles, \\
$\mu \mathrm{m}$
\end{tabular}} & \multicolumn{6}{|c|}{$\begin{array}{l}\text { Cumulative of heat evolution } \\
\text { due to slag reaction, } \mathrm{J} / \mathrm{g}\end{array}$} \\
\hline & & $12 \mathrm{~h}$ & $24 \mathrm{~h}$ & $36 \mathrm{~h}$ & $48 \mathrm{~h}$ & $60 \mathrm{~h}$ & $72 \mathrm{~h}$ \\
\hline LGGBF50-LGRS50 & \multirow{3}{*}{$18 \pm 1$} & -5.9 & -8.0 & -6.7 & -5.0 & -2.7 & 0.8 \\
\hline LGGBF60-LGRS60 & & -7.1 & -6.3 & -4.4 & -0.8 & 2.9 & 7.3 \\
\hline LGGBF70-LGRS70 & & -6.1 & -6.2 & -2.7 & 3.0 & 9.3 & 16.0 \\
\hline SGGBF50-SGRS50 & \multirow{3}{*}{$5 \pm 1$} & -11.7 & -10.4 & -5.4 & 2.2 & 10.4 & 19.3 \\
\hline SGGBF60-SGRS60 & & -10.6 & -9.9 & -1.9 & 8.3 & 19.3 & 31.1 \\
\hline SGGBF70-SGRS70 & & -9.8 & -8.8 & 0.5 & 14.3 & 29.2 & 42.7 \\
\hline
\end{tabular}

Table 6 shows the values of the cumulative heat evolution of pastes due to the slag reaction. The differences in cumulative heat evolution for the pastes LGGBF50 and LGRS50 (LGGBF50-LGRS50) at 12, 24, 36, 48, 60, and $72 \mathrm{~h}$ were $-5.9,-8.0,-6.7,-5.0,-2.7$, and $0.8 \mathrm{~J} / \mathrm{g}$, respectively, while those for the pastes SGGBF50-SGRS50 were $-11.7,-10.4,-5.4,2.2,10.4$, and $19.3 \mathrm{~J} / \mathrm{g}$, respectively. The minus sign indicates that the use of GGBF slag (LGGBF or SGGBF paste) in the paste resulted in a lower cumulative heat evolution compared to GRS paste (LGRS or SGRS). This suggests that, when Portland cement type I was replaced by GGBF slag, regardless of its particle size (smaller or larger, up to a $d_{50}$ of $18 \mu \mathrm{m}$ ), there was no apparent cumulative heat evolution due to the slag reaction during the first $24 \mathrm{~h}$. This result also indicates that the GGBF slag retards the cement hydration at an early age.

At $72 \mathrm{~h}$, the values of the cumulative heat evolution due to the slag reaction of the LGGBF50, LGGBF60, and LGGBF70 pastes were $0.8,7.3$, and $16.0 \mathrm{~J} / \mathrm{g}$, respectively whereas those of the SGGBF50, SGGBF60, and SGGBF70 pastes were $19.3,31.1$, and $42.7 \mathrm{~J} / \mathrm{g}$, respectively. This finding suggests that the cumulative heat evolution due to the slag reaction increases with the decrease of particle size and cement replacement by GGBF slag. The results also indicate that SGGBF and LGGBF slags have slow reaction at early age, which is due to low hydraulic activity and leads to the low early compressive strength as generally found when GGBF slag is used to replace OPC in concrete [31-33].

It should be noted that paste containing GGBF slag with the highest cumulative heat evolution did not necessarily have the highest slag reaction. For example, the cumulative heat evolution of the pastes SGGBF50 and SGGBF70 during the first $72 \mathrm{~h}$ was 218.5 and $170.7 \mathrm{~J} / \mathrm{g}$ while their cumulative heat evolution due to the slag reaction was 19.3 and $42.7 \mathrm{~J} / \mathrm{g}$, respectively. This suggests that, for the same particle size of GGBF slag, the cumulative heat evolution due to the slag reaction depended on the dosage of cement replacement by the GGBF slag.

\section{CONCLUSIONS}

When using ground river sand with the median particle sizes $\left(d_{50}\right)$ of 4.8 and $17.7 \mu \mathrm{m}$ to replace Portland cement type I at the same replacement of $50-70 \%$ by weight of the binder, the cumulative heat evolution of both pastes are nearly the same during the first $72 \mathrm{~h}$.

The cumulative heat evolution due to the slag reaction increased with the decrease of GGBF slag particles. Moreover, the cumulative heat evolution at $72 \mathrm{~h}$ of GGBF slag was much lower than that of Portland cement.

At $24 \mathrm{~h}$, the use of GGBF slag to replace Portland cement type I at $50-70 \%$ by weight of the binder could reduce the cumulative heat evolution because GGBF slag acted like a retarder and the values of the cumulative heat evolution of pastes containing GGBF slag at $72 \mathrm{~h}$ were low.

When GGBF slag with $d_{50}$ of $4.4 \mu \mathrm{m}$ was used to replace OPC at 50,60, and $70 \%$ by weight of the binder, the cumulative heat evolution of GGBF slag pastes at $24 \mathrm{~h}$ were $56.6,46.3$, and $35.1 \%$ that of OPC paste and increased to $70.1,62.6$, and $54.7 \%$ that of OPC paste at $72 \mathrm{~h}$, respectively. In addition, the use of GGBF slag with $d_{50}$ of $17.8 \mu \mathrm{m}$ to replace OPC at 50,60 , and $70 \%$ by weight of the binder had the cumulative heat evolution of 54.2, 44.6, and $33.8 \%$ that of OPC paste at $24 \mathrm{~h}$, and it increased to $59.9,52.2$, and $43.9 \%$ that of OPC paste at $72 \mathrm{~h}$.

The use of GGBF slag with $\mathrm{d}_{50}$ of $17.8 \mu \mathrm{m}$ to replace OPC at 50,60 , and $70 \%$ by weight of the binder produced a cumulative heat evolution at $72 \mathrm{~h}$ due to the slag reaction of $0.8,7.3$, and $16.0 \mathrm{~J} / \mathrm{g}$, respectively, while the use of GGBF slag with $d_{50}$ of $4.4 \mu \mathrm{m}$ had a cumulative heat evolution due to the slag reaction at $72 \mathrm{~h}$ of $19.3,31.1$, and $42.7 \mathrm{~J} / \mathrm{g}$, respectively.

\section{Acknowledgments}

The authors gratefully acknowledge the financial support from the Office of the Higher Education Commission under National Research University (NRU) at King Mongkut's University of Technology Thonburi. Thanks are also extended to the Siam Research and 
Innovation Co., Ltd for providing facilities and equipment for this study.

\section{REFERENCES}

1. ACI 233R-03. Slag Cement in Concrete and Mortar ACI Manual of Concrete Practice 2012: pp. 1-19.

2. Bellmann, F., Stark, J. Activation of Blast Furnace Slag by a New Method Cement and Concrete Research 39 (8) 2009: pp. $644-650$.

3. Boukendakdji, O., Kadri, E.H., Kenai, S. Effects of Ground Granulated Blast Furnace Slag and Superplasticizer Type on the Fresh Properties and Compressive Strength of Self-Compacting Concrete Cement and Concrete Composites 34 (4) 2012: pp. 583-590. https://doi.org/10.1016/j.cemconcomp.2011.08.013

4. Sivasundaram, V., Malhotra, V.M. Properties of Concrete Incorporating Low Quality of Cement and High Volumes of Ground Granulated Slag ACI Materials Journal 89 (6) 1992: pp. $554-563$.

5. Guneyisi, E., Gesoglu, M. A Study on Durability Properties of High Performance Concretes Incorporating High Replacements of Slag Materials and Structures 41 2008: pp. 479-493.

6. Bouikni, A., Swamy, R.N., Bali, A. Durability Properties of Concrete Containing 50\% and 65\% Slag Construction and Building Materials 23 (8) 2009: pp. 2836-2845. https://doi.org/10.1016/j.conbuildmat.2009.02.040

7. Metha, P.K. Reducing the Environmental Impact of Concrete Concrete International $23(10)$ 2001: pp. $61-66$.

8. Kurt, M., Gul, M.S., Gul, R., Aydin, A.C., Kotan, T. The Effect of Pumice Powder on the Self-Compactability of Pumice Aggregate Lightweight Concrete Construction and Building Materials 103 2016: pp. 36-46.

9. Shi, C., Day, R.L. A Calorimetric Study of Early Hydration of Alkali-Slag Cement Cement and Concrete Research 25 (6) 1995: pp. $1333-1346$. https://doi.org/10.1016/0008-8846(95)00126-W

10. Zhang, T., Yu, Q., Wei, J., Gao, P., Zhang, P. Study on Optimization of Hydration Process of Blended Cement Journal Thermal Analysis and Calorimetry 107 2012: pp. 489-498. https://doi.org/10.1007/s10973-011-1531-8

11. Siler, P., Kratky, J., De Belie, N. Isothermal and Solution Calorimetry to Assess the Effect of Superplasticizers and Mineral Admixtures on Cement Hydration Journal Thermal Analysis and Calorimetry 107 2012: pp. 313-320.

12. Gruyaert, E., Robeyst, N., De Belie, N. Study of Hydration of Portland Cement Blended with Blast Furnace Slag by Calorimetry and Thermogravimetry Journal Thermal Analysis and Calorimetry 102 2010: pp. 941-951.

13. Douglas, E., Elola, A., Malhotra, V.M. Characterization of Ground Granulated Blast Furnace Slag and Fly Ashes and their Hydration in Portland Cement Blends Cement and Concrete Aggregates 12 (2) 1990: pp. 38-46.

14. Bougara, A., Lynsdale, C., Milestone, N.B. Reactivity and Performance of Blast Furnace Slags of Differing Origin Cement and Concrete Composites 32 (4) 2010: pp. 319-324.

15. Han, F., Zhang, Z., Wang, D., Yan, P. Hydration Kinetics of Composite Binder Containing Slag at Different
Temperatures Journal Thermal Analysis and Calorimetry 121 (2) 2015: pp. 815-827.

16. Ma, W., Sample, D., Martin, R., Brown, P.W. Calorimetric Study of Cement Blends Containing Fly Ash, Silica Fume, and Sag at Elevated Temperatures Cement and Concrete Aggregates 16 (2) 1994: pp. 93-99.

17. ACI 207.1R-05. Guide to Mass Concrete ACI Manual of Concrete Practice 2012: pp. 1-30.

18. Gajda, J., Geem, M.V. Controlling Temperatures in Mass Concrete Concrete International 24 (1) 2002: pp. 59-62.

19. Metha, P.K. Durability: Critical Issues for the Future Concrete International 19 (7) 1997: pp. 27-33.

20. ISO 13320-09. Particle Size Analysis-Lazer Diffraction Methods, International Standard, 2009: pp. 1-56.

21. ASTM C 188: Standard Test Method for Density of Hydraulic Cement, 2014.

22. ASTM C 430: Standard Test Method for Fineness of Hydraulic Cement by the 45- $\mu$ m (No.325) Sieve, 2014.

23. Jaturapitakkul, C., Tangpagasit, J., $\quad$ Songmue, S., Kiattikomol, K. Filler Effect and Pozzolanic Reaction of Ground Palm Oil Fuel Ash Construction and Building Materials 25 (11) 2011: pp. 4287-4293.

24. Tangpagasit, J., Cheerarot, R., Jaturapitakkul, C., Kiattikomol, K. Packing Effect and Pozzolanic Reaction of Fly Ash in Mortar Cement and Concrete Research 35 (6) 2005: pp. $1145-1151$.

25. Yang, Q., Zhang, S., Huang, S., He, Y. Effect of Ground Quartz Sand on Properties of High Strength Concrete in the Steam Autoclaved Curing Cement and Concrete Research 30 (12) 2000: pp. $1993-1998$.

26. ASTM C 1702: Standard Test Method for Measurement of Heat of Hydration of Hydraulic Cementitious Materials using Isothermal Conduction Calorimetry, 2014.

27. Sinsiri, T., Chindaprasirt, P., Jaturapitakkul, C. Influence of Fly Ash Fineness and Shape on the Porosity and Permeability of Blended Cement Pastes International Journal of Mineral, Metal, metallurgy, and Materterials 17 (6) 2010: pp. 683-690.

28. Kiattikomol, K., Jaturapitakkul, C., Tangpagasit, J. Effect of Insoluble Residue on Properties of Portland Cement Cement and Concrete Research 30 (8) 2000: pp. $1209-1214$. https://doi.org/10.1016/S0008-8846(00)00315-X

29. Moosberg-Bustnes, H., Lagerblad, B., Forssberg, E. The Function of Fillers in Concrete Materials and Structures 37 (2) 2004: pp. $74-81$.

30. De Weerdt, K., Ben Hara, M., Le Saout, G., Kjellsen, K.O., Justnes, H., Lothenbach, B. Hydration Mechanisms of Ternary Portland Cements Containing Limestone Powder and Fly Ash Cement and Concrete Research 41 (3) 2011: pp. 279-291.

31. Bougara, A., Lynsdale, L., Ezziane, K. Activation of Algerian slag in mortars Construction Building Material 23 (1) 2009: pp. $542-547$.

32. Shariq, M., Prasad, J., Masood, A. Effect of GGBFS on Time Dependent Compressive Strength of Concrete Construction and Building Materials 24 (8) 2010: pp. 1469 - 1478.

33. Daequennes, A., Espion, B., Staquet, S. How to Assess the Hydration of Slag Cement Concrete Construction and Building Materials 40 2013: pp. $1012-1020$. 